\title{
Traditional Complementary Foods: A Critical Review
}

\section{Akinsola A. O. ${ }^{1 *}$, Onabanjo O. O. ${ }^{2}$, Idowu M. A. ${ }^{3}$, and Ade-Omowaye B. I. O. ${ }^{4}$}

\author{
${ }^{1}$ Department of Home Economics, Federal College of Education (Special), Oyo. Nigeria \\ ${ }^{2}$ Department of Home Management Science, P.M.B 2240, Federal University of Agriculture, \\ Abeokuta, Ogun State, Nigeria. \\ ${ }^{3}$ Department of Food Science and Technology, P.M.B 2240, Federal University of Agriculture, \\ Abeokuta, Ogun State, Nigeria. \\ ${ }^{4}$ Department of Food Science and Engineering, Ladoke Akintola University of Technology, \\ Ogbomoso, Oyo State, Nigeria
}

\section{ARTICLE INFO}

Article No.: 092217137

Type: Research

DOI: 10.15580/GJAS.2017.9.092217137

Submitted: 22/09/2017

Accepted: 04/10/2017

Published: 13/11/2017

${ }^{*}$ Corresponding Author

Akinsola A. $O$.

E-mail: akinsola4gold@gmail.

Com

\section{Keywords:}

Breastmilk, health risks, malnutrition, PEM, traditional complementary foods

\section{ABSTRACT}

Traditional complementary foods are popular minimally processed baby food used to introduce old infants and young children to adult foods. Cereal grains are it main ingredient, when cooked, because of its starch content, get gelatinized and swollen thereby making the diet viscous and bulky, so that it gives the stomach of old infants and young children enormous work to do. Traditional complementary foods consumed by old infants in many parts of the third world are deficient in essential macronutrients and micronutrients leading to malnutrition, which is one of the serious problems in developing countries. Protein energy malnutrition (PEM) generally occurs during this growing stage when children are weaned from breastmilk to semi-solid and later to family foods. The purpose of this study is to review literature findings on complementary foods. It's also aims to draw the attention of stakeholders and decision makers on the need to assess the nutrients quality and health risks associated with the consumption of low quality complementary foods and, consequently, the necessary measures and steps to reduce intake of low quality complementary foods by old infants and young children. 


\section{INTRODUCTION}

Complementary foods are formulated food mixtures meant to be fed along with breast milk for infants from 6 months until completely weaned off breast milk (FAO/WHO, 2002), while weaning is the process of gradual withdrawal of breast-milk which is no longer sufficient to meet the nutritional requirements of infants and introduction of other foods and liquids known as complementary foods, to complement the breast milk and then to replace it with family diets (Dewey \& Brown, 2003; Onabanjo et al., 2008; Anigo et al., 2009; Igyor et al. 2010). Thus, in a weaning process there is always the need to introduce soft, easily swallowed foods to supplement the infant's feeding early in life. The weaning process may be gradual, lasting for months until the infant is finally introduced to the family diet. In Nigeria, traditional complementary foods are usually introduced to the young children between 3 and 6 months depending on the locality and types of cereal grain and root crop available (Onofiok \& Nnanyelugo, 2007). The usual first complementary food is called pap, "akamu", "ogi", or "koko" and is made by fermentation of maize, millet, or guinea corn (Ikujendola \& Fashakin, 2005; Onabanjo, 2007). After the successful introduction of cereal gruel, other staple foods in the family menu are given to the child; such foods include yam, rice, gari, and cocoyam, which may be eaten with sauce or soup (Onofiok \& Nnanyelugo, 2007; Ikegwu, 2010).

Research has shown that fermentation of cereal grains to produce ogi (complementary food) not only removes part of its kernel such as seed coat and germ, but also involves washing, sieving and decanting, all of which induce changes in the chemical composition and nutritive value of the final fermented complementary food (Akinrele, 1970; Banigo et al., 1974; Akingbala et al., 1981; Adeyemi, 1983; Brown et al., 1998; Onofiok \& Nnanyelugo, 2007; Ezeocha \& Onwuka, 2010). Cereal based traditional complementary foods commonly fed to infants are inadequate to meet daily nutrients, energy and micronutrient requirements, where such complementary foods form the main source of nutrient to an infant, it may lead to the problems of under-nutrition and micronutrient malnutrition in infants and young children (Anju, 2002; WHO, 2002; Amina \& Agle, 2004; lgyor et al., 2010). Malnutrition in childhood could predispose a child to chronic diseases including high blood pressure, diabetes, and stroke later in life (WHO, 2003; Anigo et al., 2009). The major cause of childhood micronutrient deficiencies is attributed to a variety of factors such as intake and chemical forms of minerals, food processing practices, and presence of other dietary factors that may enhance or inhibit mineral bioavailability, health, and physiological status of the individual (Gibson, 2000; lgyor et al., 2010).

Moreover, traditional complementary foods tend to be given in form of a gruel which has gelatinized, become bulky during cooking, and increased in viscosity, whereas the digestive system of a young child that will eat it is such that only gruel of light fluid consistency can be swallowed without choking (Sanni et al., 1999; Amina \& Agle, 2004; Igyor et al., 2010). Cereal based diets are generally low in protein quality as a result of been limited in some essential amino acids particularly lysine and tryptophan, which is necessary for the growth and development of old infants and young children (Ikujendola \& Fashakin, 2005; Onofiok \& Nnanyelugo, 2007; Muhimbula et al. 2011). Many researchers, food technologists, food scientists, nutritionists, etc, have worked extensively on how to improve the nutrient value of existing complementary foods by trying to combine cereals, legumes, and other staples in such a way that will maximize the efficiency of their proteins for weaning babies. For instance, Fashakin et al., (1986) developed a complementary food using corn gruel and melon seed (ogi and melon protein) and reported that the mix was superior to corn ogi and could be used as complementary food for old infants and young children.

Abbey and Nkanga (1988) evaluated a blend of cowpea flour, maize flour, sucrose and palm oil, and found out that the best mixture had a protein efficiency ratio of 1.69 , net protein utilization of $62.2 \%$, true digestibility of $78.5 \%$ and biological value of $76.5 \%$. They reported that it could be used as alternative complementary food for old infants and young children, and there was no significant difference between the animals fed with the standard diet and those fed with the cowpea-supplemented diets. It was concluded in the study that the diet which comprised of $19.72 \%$ germinated cowpea and $59.15 \%$ maize could serve as a source of quality protein for feeding young children. Idowu et al. (1993) formulated complementary food from pre-gelatinized maize-potato mixture fortified with soybean and groundnut, and reported that it could be used as supplementary food for infants, while Olusanya (1998) formulated 30 different diets based on the principles of multi-mixes, but evaluated the protein quality of seven of them. He obtained protein efficiency ratio ranging from 1.7 to 2.7 , net protein ratio of 1.6 to 4.8 and true digestibility values ranging from 81.3 to $87.7 \%$, and recommended that the formulation is good for feeding babies.

Omueti et al. (2000) also evaluated a blend of freshly blanched soybean and grains of harvested green field maize (soy-corn) mixed in different ratios. This product called soy-corn "milk" according to the researchers can be used for combating malnutrition in developing countries. Ikujendola \& Fashakin (2005) developed a complementary food from maize and cowpea (cowpea-ogi) and reported that the complementary food could be used to feed infants with addition of milk, and food supplement, while Walker \& Pavitt (2007) carried out experiment on the energy density of third world weaning foods and reported that most traditional complementary foods energy density 
meet recommended daily allowance for old infants and young children, but low in protein quality. Other relevant contributors include Martin et al. (2010) who formulated a soybean based complementary food and reported that it could be used to complement a baby's food, while Anigo et al. (2010) observed that no single protein from a particular legume grain could be adequate to promote growth or enhance nitrogen retention compared to a milkbased diet. It could therefore be concluded that the search for local foodstuffs in the formulation of nutritionally adequate complementary food has long been in existence and is still in progress. A mixture of maize, millet, and soybean therefore could provide adequate nutrient intake for a child if well processed. Millet, one of the raw materials used in this study, has been reported to be richer in protein, vitamin B-complex, and ash content $(\mathrm{Ca}, \mathrm{P}, \mathrm{Mg}, \mathrm{Fe}$ ) than most cereal grains (Ihekoronye \& Ngoddy, 1985). Soybean on the other hand, would provide the complementary food with minerals, vitamin Bcomplex, fat and protein; especially lysine and tryptophan which are deficient in cereal grains and thus possess great potential in overcoming protein-energy malnutrition in infants and young children (Dhingra \& Jood, 2001).

Moreover, pro-vitamin A (carotenoid) found in yellow maize and finger millet would make a formulated complementary food from maize, millet, and soybean a health complement to infants and young children diets. Processing methods such as fermentation, germination, roasting, boiling, grilling, steaming, etc, have also been shown to have significant effect on the nutrient density, bulkiness, and viscosity of most traditional complementary foods (Ikujenlola \& Fashakin 2005; Anigo et al., 2010). Fermentation is a common way of preserving food, improving digestibility and increasing appetizing flavours (Dewey \& Brown, 2003; lgyor et al., 2010). During fermentation, proteins are broken down to amino acids; starches are converted into simple sugars, while riboflavin and niacin content increase, vitamins such as $B_{12}$ are synthesized and the amount of available iron is increased because some anti-nutrients such as phytate which chelate minerals are removed (Onofiok \& Nnanyelugo, 2007; Ezeocha \& Onwuka, 2010). Ogi, a fermented product of maize is a common complementary food in Nigeria used for weaning infants and young children (Akinrele, 1970; Brown et al., 1998). Traditional processing of ogi has been reported to have a number of slight processing variations (fermentation method) which could have effect on the composition and quality of the final product (Banigo et al., 1974; Akingbala et al., 1981; Adeyemi, 1983; Brown et al., 1998; Onofiok \& Nnanyelugo, 2007; Ezeocha \& Onwuka, 2010). For instance, Ikujendola and Fashakin (2005) reported that protein, minerals and some vitamins especially the water soluble ones are lost during fermentation of maize and subsequent processing into ogi, while its riboflavin content seemed to depend on the type of microorganisms involved in the fermentation.

Germination on the other hand could improve nutritive value, and increase digestibility, appetizing flavours are also developed and palatability is improved.
Sprouting also has been reported to reduce anti-nutrients in legumes such as phytate and flatulent factors (Babajide, 1998). Muhimbula et al. (2011) also reported that germination as a processing method increases starch and protein digestibility, bio-availability of vitamins and minerals, and causes a decrease in antinutrient factors of such food products. In soybean, sprouting has been shown to reduce anti-nutritive factors such as trypsin inhibitors and hemagglutinins (Oshaug \& Haddad, 2002; Aminu et al., 2010). When flour of germinated grain is used, the concentration of the gruel can be increased 3 5 times while maintaining the same viscosity as that of gruel of ungerminated flour (Dewey \& Brown, 2003). Apart from fermentation and germination methods, roasting have also been found to improve colour, flavour, and overall acceptability of some food products. Roasting method could reduce moisture content in order to improve storage stability, and also develop desirable colour and flavour. Roasting also reduces anti-nutritional factors (protease inhibitor and lectins, phytic acids, oxalic acids, and tannin) of composite flours (Keku, 2006). Onuorah \& Akinjide (2004) reported that during roasting some chemical changes take place such as pyrolysis of proteins to amino acids, destruction of the reducing sugar and browning of food products and these if not controlled, some of the most valuable nutrients needed by the baby could be lost. A complementary food developed from fermentation, germination, and roasting singly or combined therefore would be expected to provide adequate nutrient for a child and have long shelf life. Most of the previous researchers on complementary foods did not report storage stability and shelf life of their complementary foods, while many are also silent on the safety and toxicity (aflatoxin) of the products. Therefore, the goal of this review is to look into the complementary food in totality

\section{Complementary Foods}

Complemenatary foods in Nigeria are often given to babies as gruels. Research have shown that traditional complementary foods do not contain more than 10 $12 \%$ dry matter, the rest is water due to the fact that the gruel gets gelatinized during cooking and increase in viscosity (Simango, 1997). During feeding, the gruel is usually diluted with water to make it digestible for the young child and at the same time avoid choking (Juke et al., 2002; Rapley, 2006). After the successful introduction of cereal gruel, other staple foods in the family menu are given to the child; such foods include yam, rice, gari, and cocoyam, which may be eaten with sauce or soup (Onofiok \& Nnanyelugo, 2007; Ikegwu, 2010). People from low-income groups seldom feed their infants with meat, eggs, or fish, because of socioeconomic factors, taboos, and ignorance (Nnanyelugo, 1985; Onofiok \& Nnanyelugo, 1992). Cherian (1981) and Onabanjo (2007) reported that people from highincome groups used these foods more often and tended to add variety to their weaning foods. 
Legumes are rarely used for weaning and are introduced much later (after six months of age) because of the problems of indigestibility, flatulence, and diarrhea associated with their use (Uwaegbute \& Nnanyelugo, 1987; Solomon, 2005). However, Uwaegbute \& Nnanyelugo (1987) noted that $67 \%$ of their study population satisfactorily used cowpea products for weaning. Armar-Klemesu \& Wheeler (1987) reported that in Ghana, the main complementary food for infants up to six months of age was a traditional fermented maize porridge (koko) and from six months onwards, the infants were given the family diet with complementary breastfeeding. Most traditionally used processing methods have resulted in the loss of other nutrients apart from protein. Makinde \& Lachance (1976) reported a $98 \%$ loss of the original tryptophan in maize during the processing of ogi. In Anambra State, Nigeria, Agu (1976) observed that pap contained only $0.5 \%$ protein and less than $1 \%$ fat, as compared to $9 \%$ protein and $4 \%$ fat in the original corn. Indeed, Akinrele and Edwards (1971) reported that the protein content of pap ogi was too low, even to support the growth of rats, Ketiku and Ayoku (1984) noted that corn gruel can only provide some energy, but not other nutrients needed for growth of the baby. Onofiok and Nnanyelugo (2007) similarly noted that the traditional millet gruel used for weaning Senegalese children was not energy dense and was insufficient to cover all the nutrient needs of the infant (Table 1).

Table 1: Traditional complementary foods fed by West African mothers

\begin{tabular}{|c|c|c|c|c|}
\hline Country & Food & $\begin{array}{l}\text { Major nutrient } \\
\text { composition }\end{array}$ & $\begin{array}{l}\text { Introduction } \\
\text { month }\end{array}$ & Description \\
\hline Nigeria & $\begin{array}{l}\text { Ogi, pap, } \\
\text { akamu, koko }\end{array}$ & Carbohydrate & $3-6$ & $\begin{array}{l}\text { Fermented cereal from maize, } \\
\text { sorghum, or guinea corn. }\end{array}$ \\
\hline Ghana & Koko, Kenkey & Carbohydrate & $3-6$ & Fermented corn porridge. \\
\hline $\begin{array}{l}\text { Sierra- } \\
\text { Leone }\end{array}$ & $\begin{array}{l}\text { Ogi, couscous } \\
\text { ogi }\end{array}$ & Carbohydrate & $4-6$ & $\begin{array}{l}\text { Cereal gruel from fermented } \\
\text { maize, or sorghum. }\end{array}$ \\
\hline Benin & Ogi & Carbohydrate & $3-6$ & $\begin{array}{l}\text { Cereal gruel from fermented } \\
\text { maize, sorghum, or millet. }\end{array}$ \\
\hline Senegal & Ogi & Carbohydrate & $3-6$ & $\begin{array}{l}\text { Cereal gruel from fermented } \\
\text { maize or millet }\end{array}$ \\
\hline
\end{tabular}

Source: Onofiok and Nnanyelugo, 2007.

Agyepong and Vallen (1991) reported that in 1987 Ghanaian National Survey, $58 \%$ of the Ghanaian children were below $80 \%$ weight-for-weight age, $8 \%$ suffered from severe malnutrition, $40 \%$ were wasted, and $52 \%$ were stunted. Amar-Klemesu and Wheeler (1991) observed that $30 \%$ of the infants who were fed cereal porridge and adult foods as complementary foods were malnourished as a result of inadequate complementation with breast milk. Jonsyn (1985) reported that ogi prepared from maize or sorghum (couscous ogi), a popular complementary food in Sierra Leone was found to be inadequate in meeting the nutrient needs of the baby (Table 1). According to Onabanjo (2007), Demographic and Health Survey (DHS) of children aged 6 to 36 months in Ondo State, Nigeria, showed $28 \%$ prevalence for underweight, $32 \%$ for stunting, and $7 \%$ for wasting. It is therefore clear that during the period of weaning, children in West Africa are very vulnerable to malnutrition, and one of the major factors that causes stunting or what makes some children appear stunted can be traced to inadequate food intake. Children in West Africa are therefore at high risk of infection during weaning.

Malnutrition increases susceptibility to infectious diseases and affects child mortality from diseases such as diarrhea, whooping cough, acute respiratory infection and reduces the capacity of the host to resist the consequences of such infection, thereby making death inevitable for some. However, available statistics from Nigeria shows that infant mortality is responsible for almost $50 \%$ of all the deaths of children up to 14 years of age, and under-five mortality accounts for $93 \%$ of these deaths, $70 \%$ of which are attributed to preventable diseases (Onabanjo, 2007). According to Cameron and Hofvander (1983), the simplest recipe for complementary food called multi-mix is one which has a basic mix of cereal or starchy root/tuber mixed with legume. Appropriate use of low cost, affordable formulated complementary foods with emphasis on vegetable source of protein has been recommended for the developing countries (Dewey \& Brown, 2002; Lutter \& Dewey, 2007). Being a complement to breast milk, such diets should provide enough energy and nutrients that are needed to meet increasing physiological requirements of the young children and at the same time support growth and development.

\section{Raw materials commonly used for tradition complementary foods}

The International Programme of Complementary Food Mixtures is aimed at developing products whose ingredients are produced locally (FAO/WHO, 1991). In selecting the raw materials, attention should be paid to 
availability, maturity and processing method employed as this will affect the acceptability of the final product. Also, it is necessary to realize that the complementary food must be acceptable to the mother before she will agree to feed her baby with the product. The raw materials commonly used are cereal grains and legume.

\section{Cereal grains}

Cereal grains which belong to the family graminaeae are the most widely cultivated and consumed crops on a global basis. It is also a staple food of the people in the tropics where it provides about $75 \%$ of their total caloric intake and $67 \%$ of their total protein intake (WHO, 1998; Rapley, 2006). In Nigeria, especially in the Northern part of the country, cereals are the major sources of energy and protein in the diets of the people. The major cereals cultivated are sorghum, millet, maize and rice; together these four crops occupied an estimate of over 16 million hectares of farmland (Okoh, 1998). The structure of all cereal grains is basically similar, differing from one cereal to another in detail only. The composition of mature cereal grains consist mainly of carbohydrates, proteins, lipids, mineral salts, water and vitamins which are present in small quantities (Okoh, 1998). Several reports on the major chemical composition of cultivated cereals in Nigeria have been given as proximate composition (Adeyeye \& Ajewole, 1992; Ngwu, 2005). Compared with root and tuber crops, cereals offer a better source of protein in the diet of Nigerians whose intake of protein from animal sources is low. However, the nutritional quality of most cereal protein is poor because they contain less of the essential amino acids, particularly lysine, needed for growth and maintenance (Juke et al., 2002; Okoh et al., 1985).

The major protein of cereals responsible for the poor biological value of the grain is prolamine. Protein quality is inversely related to its prolamine content, that is the lower the prolamine content the higher the protein quality, although there may be several other interacting factors (Onabanjo et al., 2008). The protein values of major cereals grown in Nigeria according to Okoh (1998) are quite different, ranging from 6.96 to $13.69 \mathrm{~g}$. Millet and wheat have slightly higher protein contents of 13.69 and $11.63 \mathrm{~g} / 100 \mathrm{~g}$ than maize, sorghum, and rice with $10.03 ; 9.28$, and $7.07 \mathrm{~g} / 100 \mathrm{~g}$, respectively. Acha, a lesser known cereal in Nigeria has remarkably lower protein content of $6.96 \%$. Apart from rice with mineral salts content of $0.56 \%$, the rest of the cereals have mineral salts ranging from $1.16-2.44 \%$. The crude fat content in acha of $2.10 \%$ is similar to those of sorghum, rice and wheat with $2.27,2.25$, and $2.33 \%$, respectively, but lower than the values of maize and millet $2.54 \%$ and $5.39 \%$, respectively (Okoh, 1998). Okoh et al., (1985) reported that cereal protein is of low nutritional quality because they contain less of essential amino acids especially lysine needed for growth and maintenance.

Cereals, therefore needs to be fortified with a high protein rich food such as soya beans, groundnuts, cowpeas, bambara beans, etc. (Okoh, 1998). According to Ihekoronye and Ngoddy (1985), most cereals have high carbohydrate content ranging from 68 to $83 \%$ in oats and maize, respectively; while their protein content is between 6.96 in acha to $13.69 \%$ in corn. The writers reported that except for the two amino acids (lysine and tryptophan), most cereals contain the essential amino acids required by man as well as vitamins and minerals. Adeyeye and Ajewole (1992) reported the chemical composition of cereal grains cultivated in Oyo State, Nigeria and showed that rice has the least amount of crude protein compared with cultivated sorghum, millet and maize. The report by Nwasike et al., (1987) on the proximate, mineral and amino acid composition of early and late maturing Nigerian millets showed that the total seed protein was higher in the late maturing millets and ranged from 14.09 to $17.14 \%$, while the protein in the early maturing millets ranged from 12.30 to $13.69 \%$. Compared with Nigerian sorghum varieties, millets have higher protein content and were found to be superior in their most limiting amino acid content (Okoh, 1998).

\section{Significance of morphology and structure in cereal grain processing}

The work of several authors have clearly shown that, without a full understanding of the grain morphology and structure, the studies on technological and product quality characteristics will not be complete in cereal grains (Srinivas et al., 1991). The main constituent of cereal grains, which make them important in food preparations are their starch and protein contents. The behaviour of cereal grain starch, like any other starch such as corn starch is to thicken and form a gel. Kordylas (1990) reported that this ability makes starch in cereal grains a very important ingredient in food preparation where thickening and gel formation are desirable. Hence, the determining factors of grain morphology and structure are inherent in the parent plants. Texture of grains is another factor that largely affects the end product quality of maize and other cereal grains. This determines the product acceptability by the consumer (Adeyemi, 1983; Onuorah \& Akinjide, 2004; Ikegwu, 2010). The endosperm texture (vitreousness) is commonly associated with hardness and dry-milling behaviour of cereal grains and a good breeding indicator of grain quality (Mestres et al., 1995). Carcea and Acquistucci (1997) reported that the starch granules of maize show deep indentations on their surfaces. Softness and stickiness of sorghum tuwo were correlated significantly with particle size index of the flour which is determined by the texture of the kernel (Akingbala \& Rooney, 1990; Sanni et al., 2004). The existence and function of features such as pores which are often found randomly distributed over the surface of the cereal starch granules of the members of sub-family panicoideae (Fannon et al., 1992; Adebowale et al., 2005), also contributed to the texture of the cereal flours.

Starch granules absorb water, and finally the suspension thickens to form a paste, with an accompanying change in appearance of the heated 
suspension. Starch granules are primarily composed of amylose and amylopectin (Takeda et al., 1987; Wankhede et al., 1989; Adebowale et al., 2005). Takeda et al., (1987) reported that amylose is essentially a linear polymer consisting of $1-4$ linked Dglycopyranosyl units, but some amylose molecules can be slightly branched with $\mathrm{D}-(1-6)$ linkages. Amylopectin is a highly branched polymer of -Dglycopyranosyl unit, primarily linked by $1-4$ bonds, with branches resulting from $(1-6)$ linkages.

Matz (1984) recommended a $5-20 \%$ amylose level in starch to give acceptable texture with adequate crispness. Amylopectin contribute to swelling, whereas amylose and lipids inhibit swelling (Tester \& Morrison, 1990). The transition from a suspension of starch granules to a paste, when heat is applied is accompanied by a large increase in viscosity. Jideani and Akingbala (1993) reported that the starch granules of acha grains gelatinized between 76 and $78^{\circ} \mathrm{C}$, compared to that of sorghum $68-75^{\circ} \mathrm{C}$ and a bit higher than that of maize $70.1^{\circ} \mathrm{C}$. According to Oyewole and Akingbala (1993), acha has a higher gelatinization temperature than other common cereal in Nigeria. The presence of naturally occurring non-carbohydrate such as lipid is also an important factor in starch gelatinization (Mora-Escobedo et al., 1991; Sanni et al., 2001). Swinkles (1985) showed that the formation of amyloselipid complexes could restrict swelling and solubility of the starch, hence affect its rheological properties, while June et al., (1991) reported that the increase in paste viscosity when a hot paste is cooled is governed by the retrogradation tendency of the starch and this is largely determined by the affinity of hydroxyl groups in one molecule for another which occurs mainly between the amylose molecules.

\section{Legumes}

Legumes are important sources of proteins in many of the lesser developed countries and tropical areas. Legumes belong to the family Leguminosae, which is probably the second most important source of food and fodder, next only to the family Graminaeae, the cereal grains. The legume is, however a very important crop in terms of production systems since grains and fodder can be obtained with minimal investment in terms of nitrogenous fertilizers (Solomon, 2005; Ezeocha \& Onwuka, 2010). Basically, legumes are divided into three categories as food legumes, oilseeds, and forage legumes. The major types of food grain legumes and pulses are groundnuts, cowpeas, bambara nuts, broad beans, pigeon peas, beans, jack beans and soya beans (Ikujenlola \& Fashakin, 2005). Dry grains of legumes are used as sources of vegetable oil, while the defatted meals are used as sources of protein. Grain legumes (pulses) can be boiled and eaten as such or made into flour and used for various dishes. Legumes are good sources of dietary protein. They are rich in lysine and tryptophan but low in the sulphur-containing amino acids, methionine and cysteine (Anigo et al., 2009). Legumes are cheaper than animal products (meat, fish, poultry, egg) and are consumed worldwide as major source of protein, especially in the developing countries where consumption of animal protein may be limited as a result of economic, social, cultural, or religious factors. Elegbede (1998) and Anigo et al., (2010) reported that legumes are good sources of protein and energy; the protein content ranges generally from 20 to $40 \%$ for most grain while its carbohydrate content ranges from $23 \%$ in groundnut to $66 \%$ in bambara groundnut, pigeon pea, and lima bean.

Legumes, except the oilseeds are low in fat content, ranging from 1 to $5 \%$. However, oilseeds have a range of lipid content from about $18 \%$ in soybean to as high as $43 \%$ in groundnut (Osagie, 1998; Dewey \& Brown, 2003). All legume grains contain substantial amounts of minerals and vitamins, especially those of the B group. Cowpea, soybeans, and bambara groundnuts are good sources of calcium and iron with their contents being higher than those of meat, fish or eggs. These legumes also contain more thiamin, riboflavin and niacin than whole milk and cereals, with the levels of these vitamins being comparable to those available from fish, beef and egg (Elegbede, 1998; Ikujenlola \& Fashakin, 2005). The quality of a protein is usually evaluated by comparing its amino acid profile to that of the FAO/WHO/UNU (1985) standard amino acid pattern or by observing the growth performance and nitrogen balance of animals fed on a diet containing legumes as the only protein source. Thus, by combining the protein from legumes and cereals, dietary proteins of high nutritive value similar to protein from meat, fish and egg are obtained due to mutual complementation (Solomon, 2005; Martin et al., 2010). However, one of the militating factors against the use of legume without proper and adequate treatment/processing is its antinutritional factors.

\section{Antinutritional factors}

According to Bajpai et al., (2005), the nutritional value of soybean meal is much lower than expected, in spite of its protein content and amino acid profile of the proteins. This is largely attributed to the presence of antinutritional factors, such as protease inhibitors, lectins, phytate and tannins. Protease inhibitors are the most important antinutritional factor. Soybean seed also contains trypsin inhibitor, hemagglutinins, phytic acid, goitrogens and urease enzyme that may limit the nutritional value of this legume. The presence of antinutritional factors such as trypsin and chymotrypsin inhibitors in soybean lowers the digestibility of the soybean protein (Storebakken et al., 2000; Olguin et al., 2003). Other antinutritional factors like tannins, phytate, anthocyanins, and hemagglutinins impart bitter or unacceptable taste to soybean, prevent protein digestibility and decrease the absorption of divalent metal ions in the intestine (Phillips \& McWatters, 1991). These antinutrients form insoluble 
complexes with such divalent ions as $\mathrm{Fe++}, \mathrm{Zn++}$ and thus make them unavailable for absorption. Hemagglutinins are toxic protein found in soya beans. It agglutinates red blood cells, but does not affect the nutritional quality of soybean protein. The cyanogenic glycoside content of soybean represents another important factor against their widespread use, especially in areas where cassava consumption is high (Ologhobo et al., 1984; Olguin et al., 2003).

The high level of $\mathrm{HCN}$ can be reduced by different processing methods like autoclaving, cooking, soaking, fermentation and germination. The hard-to-cook phenomenon experienced with soybean and other legumes especially after long storage periods is another major constraint to the utilization of legumes. As the storage period of soybean increases, there is a tendency for the grains to develop hard-to-cook phenomenon (Phillips \& McWatter, 1991). Also, the unacceptable, beany flavour and odour associated with soybean products is caused by the enzyme lipoxygenase. The beany flavour that makes soymilk and other soybean products unacceptable can be removed by inhibiting the activity of this enzyme. However, the effects of different processing techniques such as soaking, cooking, fermentation, germination, roasting, and autoclaving on the chemical composition of soybean have been examined (Alector \& Ojo, 1989; Amina and Agle, 2004; Ikegwu, 2010), with particular reference to their inherent antinutritional components, and have been shown to cause some nutrient losses, but resulted in significant reductions of the antinutritional contents of processed foods.

\section{Nutritional quality of complementary food}

A good and quality complementary food should be nutritionally balanced, acceptable in terms of taste, appeal, colour, flavour, and storage stability (Bressani \& Elias, 1983; Onuorah \& Akinjide, 2004), and should be convenient and easy to prepare, involving few utensils and requiring short cooking and feeding times (Ikegwu, 2010). Nutrient recommendation for healthy infants must take into consideration several factors such as differential growth rates of infants, which is partly influenced by nutrition and partly by environment (Dewey \& Brown, 2003). The amount of selected protein sources that could provide the additional amino acid needs from complementary foods show that the requirements for the sulfur containing amino acids (methionine and cysteine) could be met, for example, by providing $0.18-0.48 \mathrm{~g}$ of bovine milk protein or soy protein per kilogram body weight per day or 0.65 and $0.79 \mathrm{~g}$ of cereal protein per kilogram body weight per day could provide the needed amount of lysine (Lutter \& Dewey, 2007). The nutrient requirement for healthy children according to Cameron and Hofvander (1983) is based on the average weight of $9 \mathrm{~kg}$ for a child of 9 months old; the energy requirement in food should be $900 \mathrm{kcal} /$ day. Uauy \& Castillo (2003) noted that the composition of dietary fat might be an important determinant of growth, infant development and long-term health. The fat content of infant and toddler complementary food diets is often low because of the dependence on cereal sources (Lutter \& Rivera, 2003). Uauy and Castillo (2003) recommend that between 6 months and 36 months, fat intake should be gradually reduced from between 40 and $60 \%$ to 30 and $35 \%$ of energy, while Dewey and Brown (2002) provide calculations for the percentage of lipid required from complementary foods when either 30 or $45 \%$ of energy is from lipid and the level of human milk intake is low, medium or high. These calculations show that for infants' aged 6 - 11 months, the percentage of energy from lipid that should be provided in complementary foods ranges from 0 to $24 \%$ (for $30 \%$ energy as lipid) or from 0 to $43 \%$ (for $45 \%$ energy as lipid). For children aged 12-23 months, the percentage of energy from lipid that should be provided in complementary foods ranges from 0 to $28 \%$ (30\% energy as lipid) or from 34 to $44 \%$ (45\% energy as lipid). The percentage of energy as lipid in complementary foods needed to ensure a minimum total intake of $30 \%$ energy as lipid for an infant who receives a low amount of human milk is 19,24 and $28 \%$ at ages $6-8,9-11$ and $12-23$ months, respectively. The total diet should provide infants with at least $3-5 \%$ of total energy from linolenic acid, to meet essential fatty acid requirements (Uauy \& Castillo, 2003), however, hydrogenated fish oils should be avoided (WHO, 2002).

The requirements for maintenance of body protein equilibrium as well as the optimum pattern of individual essential amino acids change little between 6 months and 24 months (Reeds \& Garlick, 2003). The calculations of the dietary requirement for whole protein suggest that a minimum protein-energy ratio of $6 \%$ in complementary foods is desirable. A methodological approach for determining the ideal proportion of macronutrients in a complementary food has not previously been proposed. Codex Alimentarius Guidelines for Formulated Supplementary Foods for Older Infants and Young Children (FAO/WHO, 1991) proposed an energy density of at least $400 \mathrm{kcal} / 100 \mathrm{~g}$ of dry food, an amino acid score of not less than $70 \%$ of that of casein, and a fat content between 20 and $40 \%$ of energy, corresponding to $10-25 \mathrm{~g}$ of fats or oils per 100 $\mathrm{g}$ of dry food, with the level of linoleic acid not less than $300 \mathrm{mg} / 100 \mathrm{~g}$ or $1.4 \mathrm{~g} / 100 \mathrm{~g}$ of dry product. Some recent abstracts showed an association between milk consumption and growth (Hoppe et al., 2003; Ruel, 2003) suggesting that milk may have a special role in child growth. The biological basis for this effect is not known, but calcium is associated with changes in body composition in favor of higher fat-free mass.

One hypothesis for this phenomenon is that branched-chain amino acids, which are abundant in dairy foods, promote growth of lean body mass. These amino acids enhance the recycling of glucose and favor muscle protein synthesis (Layman, 2003). This suggests that milk should be included in a fortified complementary food as a calcium and fat source, but information on the optimal quantity to include is not yet 
available. Data are also not available to guide a recommendation for the optimal mix of legumes and cereals or the appropriate ratio of simple to complex carbohydrates. However, it seems prudent to restrict sugar content to less than $10 \%$ of energy.

\section{Energy requirement}

Energy needs vary according to age and weight for full term infants in the first year of life. The total energy requirements of health, breastfed infants are approximately $615 \mathrm{kcal} /$ day at 6 - 8 months, $686 \mathrm{kcal} /$ day at $9-11$ months, and $894 \mathrm{kcal} /$ day at $12-23$ months of age (Dewey \& Brown, 2002; Lutter \& Dewey, 2007). Energy needs from complementary foods are estimated by subtracting average breast milk energy intake from total energy requirements at each age. Among breastfed children in developing countries, average breastmilk energy intake is 413,379 and 346 $\mathrm{kcal} /$ day at $6-8,9-11$ and $12-23$ months, respectively (WHO/UNICEF, 1988). The equivalent values for industrialized countries (breastfed children only) are 486, 375 and $313 \mathrm{kcal} /$ day, respectively. The amount of food to be offered should be based on the principles of responsive feeding, while assuring that energy density and meal frequency are adequate to meet the child's needs. The sample diets shown in the document complementary feeding: family foods for breastfed children (WHO, 2000), which have a composite energy density ranging from 1.07 to $1.46 \mathrm{kcal} /$ day, the approximate quantity of complementary foods that would meet the energy needs described above is $137-187$ $\mathrm{g} /$ day at $6-8$ months, $206-281 \mathrm{~g} /$ day at $9-11$ months, and $378-515 \mathrm{~g} /$ day at $12-23$ months.

\section{Protein requirement}

Mature human milk protein content has widely been reported to meet the protein requirements of healthy infants for the first year of life provided breast milk intake continue un-interrupted and with slight reduction in volume over the year (Dewey \& Brown, 2002; WHO, 2003). The protein quantity may be lower in breast milk produced by malnourished mothers but breast milk protein content normally falls slowly during the first four months of lactation in well-nourished mothers and falls slightly more after six months of lactation (WHO, 2002; Dewey \& Brown, 2003; Onofiok \& Nnanyelugo, 2007). About two third of the protein requirement of infants is used for growth in the first month and this gradually decreases to about $10 \%$ by the first year of the baby's life (WHO, 2003; Anigo et al., 2009). Protein requirements are related to quality measured in terms of biological value (BV), protein efficiency ratio (PER), net protein utilization (NPU), and amino acid score.

\section{Lipid requirement}

Fat is important in the diets of infants and young children because it provides essential fatty acids, facilitates absorption of fat-soluble vitamins, and enhances dietary energy density, and sensory qualities (Onabanjo et al., 2008). Human milk provides a fat-energy ratio (FER) of $50 \%$. Most of the human milk fat is provided as saturated and monounsaturated fatty acids and a relatively high cholesterol intake of $100-150 \mathrm{mg} / \mathrm{day}$ (WHO, 1998; Dewey \& Brown, 2003). The oleic acid or linoleic acid content will depend on the oil source. The use of vegetable oils in the infant diet is based on availability, nutritional properties and relative costs. The need to include linoleic acid, linolenic, and arachidonic acids (essential fatty acids) has been recognized for over 40 years (WHO, 1998). More recently the need to provide linolenic acid as a source of essential fatty acid (EFA) found in retinal and nervous system development has been recognized (WHO, 2002). The (n-6) polyunsaturated fatty acids (PUFA) are abundant in commonly used vegetable oils whereas (n-3) PUFA are relatively low except in soy, canola and linseed oils (Dewey \& Brown, 2003).

The human milk contains EFA, especially the long chain PUFA, and breast milk is generally a more abundant source of EFA than most complementary foods (Onabanjo, 2007; Onabanjo et al., 2008). Research has shown that total fat intake usually decreases with age as the contribution of breast milk to total dietary energy declines. Although there is debate about the optimal amount of fat in the diets of infants and young children, the range of $30-45 \%$ of total energy has been suggested (Bieri et al., 1999; Dewey \& Brown, 2002) as a reasonable compromise between the risks of too little intake and excessive intake although the evidence on this point is limited (Dewey \& Brown, 2002; Fermandez et al., 2002). The percentage of energy from fat in complementary foods that would be needed to achieve a level of $30-45 \%$ of energy from fat in the total diet depends on the level of breast milk intake and the fat content of the breast milk (Dewey \& Brown, 2002). Adeyeye and Ajewole (1992) reported on the fatty acid profile of cereals grown in Nigeria which shows that palmitic, oleic and linoleic acids $\left(\mathrm{C}_{16: 0}, \mathrm{C}_{18: 1}, \mathrm{C}_{18: 2 \text {, }}\right.$ respectively) were the three abundant fatty acids in the four cereals (sorghum, millet, maize, and rice) studied. All cereals showed high levels of unsaturated fatty acid ranging from $75 \%$ in millet to $86.4 \%$ in sorghum, and linoleic acid $\left(\mathrm{C}_{18: 3}\right)$ was not detectable in maize, the other three cereals had reasonable quantities between 2.2 - 7.1\%. These effects could exacerbate micronutrient malnutrition in vulnerable populations unless other measures (such as fortification) are taken to ensure adequate micronutrient intake.

\section{Micronutrient requirement}

Breast milk can only make a substantial contribution to the total nutrient intake of children between 6 and 24 months of age, particularly for protein and many of the 
vitamins. However, breast milk is relatively low in several minerals such as iron and zinc, even after accounting for bioavailability. At 9 - 11 months of age, for example, the proportion of the Recommended Nutrient Intake that needs to be supplied by complementary foods is $97 \%$ for iron , $86 \%$ for zinc, $81 \%$ for phosphorus, $76 \%$ for magnesium, $73 \%$ for sodium and $72 \%$ for calcium (Dewey, 2001). Vitamin A programme have also been demonstrated to reduce mortality rates of under-five years old children in both Africa and Asia (Davidson, 2002; Figueroa \& RodriguezGarcia, 2002). The advice to provide pro-vitamin A-rich fruits and vegetables daily is based on the clear health benefits associated with preventing vitamin A deficiency, and the likelihood that consumption of such foods will also help meet the needs for many of the other vitamins (Martin et al., 2010). Micronutrient deficiencies, particularly deficiencies of iodine, iron and vitamin $\mathrm{A}$ are major problems for school age children in low-income countries, Nigeria inclusive. It has been revealed that such deficiencies will not only negatively impact on growth and increase susceptibility to infection, but also impair the mental development and learning abilities of school children (Figueroa \& Rodridguez-Garcia, 2002; Oganah, 2005).

lodine deficiency is associated with an average 13.5 point reduction in intelligent quotient. Its deficiency in school children lead to reduced cognitive function while deficiency during fetal life could have profound and irreversible effects on the child's mental capacity and hence reduction in school performance (Oganah, 2005). It is preferable to develop population-specific dietary guidelines for complementary foods based on the composition of locally available foods. However, it is clear from previous analyses (Dewey \& Brown, 2002; Lutter \& Dewey, 2007; Igah, 2008) that; plant-based complementary foods by themselves are insufficient to meet the needs for certain micronutrients. Therefore, it is advisable to include meat, poultry, fish or eggs in complementary food diets as often as possible. In an environment with poor sanitation, promotion of liquid milk products is risky because they are easily contaminated, especially when fed by bottle. Fresh, unheated cow's milk consumed prior to 12 months of age is also associated with fecal blood loss and lower iron status (Griffin \& Abrams, 2001; WHO, 2003).

\section{Protein-energy-malnutrition (PEM)}

PEM and diarrhea are major factors responsible for the high under-five mortality in tropical countries, estimated at more than 15 million per year. The infant (less than one year) mortality rate in tropical developing countries is 15 times higher than in the industrialized regions (Nout, 1995; Ezeocha \& Onwuka, 2010). Majority of the world children are hungry and living in poverty as a result of inadequate total food intake, or imbalanced food intake (Whitney et al. 2002; UNICEF, 2009). Children become malnourished and suffer growth retardation and may lead to death among children when such hunger is chronic (Sizer \& Whitney, 2002; WHO, 2003). According to Salami and Ojo (2004), fifteen children die of malnutrition every 30 seconds but 125 children are born during the same 30 seconds, and every day the earth gains another 360,000 new residents to feed. Among the clinical symptoms of PEM are marasmus, marasmuskwashiorkor, kwashiorkor, and dwarfism. The major cases of PEM are mild and moderate cases (nearly $80 \%$ ), while the incidence of severe cases is $1-2 \%$ in pre-school age children and the problem exists in all the states of Nigeria (Onuorah \& Akinjide, 2004).

\section{Various Technological Approaches on Complementary Foods}

Processing method has been shown to have significant effect on the viscosity, dietary bulkiness, and nutrient density of most traditional complementary foods. The major food constituent in cereal-based complementary foods is the starch component. It is also considered to be the major water-binding component in these foods and to a large extent determine the dietary bulk properties (Svanberg, 1987). Processing could be in form of dry-milling, wet-milling, germination, fermentation, roasting, boiling, autoclaving, extrusion, enzyme treatment, etc. Several investigations have been carried out on the effects of simple processing techniques on the antinutritional factors in plant foods (Antai \& Obong, 1992; Solomon, 2005; lgyor et al., 2010). Osagie (1998) reported that traditional methods of processing cowpeas in Nigeria into "ewa", "gbegiri", "akara", and "moin-moin", compensate for any losses in nutrients of cowpeas associated with isolated treatments such as soaking, dehulling, and cooking. These processed products ensure a significant reduction in the antinutritional factors and maximum retention of nutrients. The effect of fermentation on phytate levels in maize, millet, rice, cowpea, and soya beans shows substantial reduction ranging from $80 \%$ to $90 \%$ in rice, and from $52-65 \%$ in maize, sorghum, soybean and cowpea (Osagie, 1998). Lowering of phytate was most rapid within the first $48 \mathrm{~h}$ of fermentation. Hence, it may be inferred that the local food processing methods (boiling, fermentation, germination, roasting, and steaming) used in Nigeria minimize the concerns posed by metal chelation and protein-binding action brought about by the phytate naturally present in food materials of plant origin (Ikujenlola and Fashakin, 2005).

\section{Milling}

Dry milling is a process whereby the whole grain, after sorting and winnowing, is milled into flour and used in flour/powder forms, retaining almost all the nutrients present in the whole grain, it is nutritionally superior to dehulled cereal products. Traditionally, maize, sorghum, millet and rice are dehulled first by pounding, followed by winnowing. The crushed grain is then ground on large grinding stones to produce dry flour. The products, therefore derived from dry milling of maize are maize 
meal, maize flour and maize grits (Akingbala \& Rooney, 1990). Other products are oil and by-products for animal feeds. Also the same source reported that particle size distribution when sample were suspended in water produce a bimodal particle size which cause differing chemical and physical properties. Adeyemi (1983) reported that dry milling of sorghum affects its texture as compared to wet milling of sorghum for ogi manufacture. According to Akingbala \& Rooney (1990), flour fractions of the smaller particle size produce softer tuwo in acid, alkalis, or neutral medium than fractions of larger particles.

Svanberg (1987) reported that there are significant differences in bulk densities of dry milled cereal flour compared to germinated cereal flour. Akingbala \& Rooney (1990) reported that dry milling procedure significantly affected flour properties, quality parameters and the amount of water required for agglomeration, while the effect of wet milling has been reported by many authors (Akingbala et al., 1981; Matilda, et al., 1993; Correia, et al., 2005). However, most wet-milling processing that have been studied extensively are fermentation of maize/millet/sorghum/guinea corn/acha to obtain a product known as Ogi.

\section{Fermentation}

Fermentation increases protein content and enhance protein quality of the cereal-based food by improving its digestibility and palatability. It also provides a better essential amino acid profile and makes its starch more available. Moreover, it also decreases the tannin content, increases the vitamin content, and appetizing flavours are developed (Cameron \& Hofvander 1993; Correia et al., 2005). During fermentation, proteins are broken down to amino acids, starches are converted into simple sugars, riboflavin and niacin contents increase (Ameny \& Hegsted, 2006; Correia et al., 2005). In addition, vitamin B is synthesized and some amount of available iron is increased because some anti-nutrients such as phytate which chelate vitamins and minerals are removed (Osagie, 1998). Fermentation is identified as an economical processing method that could be used at home to improve the nutritional quality of plant foods (Obizoba \& Atti, 1991; Obizoba \& Egbuna, 1992). The advantages of fermentation processing include overcoming the disadvantage of long cooking time, production of an easily digested product and reduction of some toxic components such as phytic acids, cyanide compound, and increase in the shelf life (Huffman et al., 2000).

The process of fermentation is particularly useful for hard seeds and could be of a short duration, overnight only or prolonged for months or even years as in the case of soy sauce (Obizoba, 1998). In Nigeria, fermented foods play a major role in the diet of the people; these include ogi from corn and gari from cassava, pito beer from millet/sorghum and different kinds of condiments. Fermented food legumes in Nigeria include the African oil bean which is widely eaten in Southern Nigeria, especially in the eastern states. It is popularly known as Ugba and could be eaten alone or mixed with other food ingredients. Melon and fluted pumpkin are fermented to produce different types of ogiri (food spices). Also, soya beans and baobab are other fermented products, replacing the locust bean seeds in the preparation of flavourings (Weingartner et al., 1987). Boralker and Reddy (1985) reported that fermentation of soybean for varying periods of 8,12 and $16 \mathrm{~h}$ caused significant increases in-vitro digestibility of it protein, while Ene-Obong (1993) observed increases in iron, magnesium, phosphorus, protein, calcium, and zinc when African yam bean was fermented for $12 \mathrm{~h}$ and $24 \mathrm{~h}$ when compared with the control and other food processing methods. Riet et al., (1987) observed that fermentation of soybean into tempeh produced favourable nutritional changes. It reduced thiamin, phytate, starch and oligosaccharides levels. It increased protein and iron, and decreased total fibre and increased loss of soluble carbohydrate and potassium.

\section{Germination}

The process of malting is essentially physiological in nature and is the result of the action of enzymes. Malting consists of the controlled germination and subsequently drying of the seed. It is known to be the most effective method of reducing viscosity of gruels and improvement in nutrient composition of the malted grains (Desikachar, 1980; Ngwu, 2005). Germination improves nutritive value of legume in terms of vitamin C, riboflavin, digestibility and appetizing flavours are developed. Nnam (2000) reported that protein content of acha expressed on a percentage dry matter increased with increased days of malting because of dry matter loss. This is because a considerable proportion of the insoluble protein is transformed into soluble components. According to Obatolu et al. (2000) malting process increases riboflavin, niacin and iron content and malted flour thicken gruels less than plain flours. The changes in the starch composition which occur during germination represent the result of localized action of alpha-amylase and to some extent beta-amylases (Lasekan, 1996; Obatolu et al., 2000). Dextrin and free sugars are liberated and there is an increased amount of damaged starch granules. Ikujenlola \& Fashakin (2005) and lgyor et al. (2010) reported that germination improve functions and nutritive value of substrates. Amino acid composition of malted sorghum showed a general increase in lysine, aspartic acid, glycine, and valine with increase in days of malting while glutamic acid, proline, phenylalanine and cystine decreased (Igyor et al., 2010).

\section{Roasting}

Roasting is always carried out to effect the following changes in food products; to further reduce the moisture 
content, improve the flavour and aroma, and to further reduce the anti-nutritional factors such as protease inhibitor, trypsin inhibitor, and lectins. Roasting brings about some chemical changes such as pyrolysis of proteins, destruction of the reducing sugar and browning of food products, enhanced flavour, and overall acceptability of such food products (Ihekoronye \& Ngoddy, 1985; Onuorah \& Akinjide, 2004). Keku (2006) reported that nutritive value and antinutritional factors of roasted maize reduces as a result of roasting. Also, Solomon (2005) and Ikegwu (2010) reported that vitamins and mineral contents of roasted and cooked maize decreased compared to the raw maize.

The gruels prepared from germinated and roasted flours have significantly lower viscosity than the gruels prepared from germinated flours at the same concentration (Okoh, 1998; Solomon, 2005). Roasting operation involve continuous stirring to ensure equal distribution of heat in order to achieve an acceptable end-products (Nout \& Ngoddy, 1995). The high temperature of 140 to $160^{\circ} \mathrm{C}$ for $2-5$ min reduces the level of protease inhibitor and lectins in soya beans and has diminishing effects on porridge viscosity (Osagie, 1998).

\section{Multiple processing methods on traditional complementary foods}

There is paucity of information concerning the use of multiple processing methods in the production of food products especially complementary foods. Multiple processing methods could provide alternative for improving the nutritional quality of food products. According to Obizoba (1998), any procedure that would increase nutrient content, quality, availability, shelf life, flavour, aroma, palatability and reduce bulkiness in legumes, cereals, roots and tubers would be of great value in Nigeria. Combining processing methods would not only produce food products adequate in nutritive value, but would be well accepted and tolerated by the targeted groups. Combination of two or more processing methods would not only increase food security and diversification, but could also alleviate the problem of protein-energy-malnutrition and its accompanying results, especially infant morbidity and mortality.

Based on the available reports of singly processed (boiling, fermentation, germination, steaming, etc) food products especially complementary foods, combining two or more of these processing methods could have greater advantage in improving biological quality, micronutrient, microbial quality and safety of such food products. Available reports show that multiple processing methods are much embraced in tea (Camellia sinensis) production technology especially in black tea manufacture. Fementation led to loss of green colour, acquiring a coppery-red shade, due to strong oxidation reactions and development of pleasants aroma of fermented tea (Ihekoronye \& Ngoddy, 1985). The fermented tea is treated with hot air or steam to inactivate enzyme (i.e. fermentation-steaming method), and then dried to a moisture content of $3 \%$. This procedure shows that subjecting an already fermented, germinated, boiled, and/or steam products to roasting would not only enhance and improve its aroma, nutrients on dry matter basis, storage stability and shelf life, but would also reduce microbial load, toxicity (aflatoxin), and antinutritional factors of such food products, especially complementary foods.

\section{Nutrition education}

Ignorance and food taboos in West Africa could have resulted to traditional complementary foods of poor nutritional quality. Improving the nutritional value of complementary foods by itself will not eliminate the problems (Salami \& Ojo, 2004). According to Juke et al. (2002), training and nutrition education of the mothers is necessary to change feeding practices and provide correct information. Health workers and nutritionists can educate rural mothers about the importance of adequate weaning foods and practices, infant health, host defense systems, home-scale drying, processing, and so on (WHO/UNICEF, 1988). The importance of varying the baby's diet and practicing good hygiene when handling and storing of baby's food can be included as well (Sizer \& Whitney, 2002; UNICEF, 2009). The teaching and training of rural mothers could have a long-term impact on weaning practices and nutritional status of West African children. In the Philippines, a weaning education programme led to a reduction in the prevalence of malnutrition from $64 \%$ to $42 \%$, and also in Nigeria the Africare Child Survival Programme yielded similar results (Nnanyelugo et al., 1990).

The development of books of recipes for complementary foods of high nutrient density using locally available foods is useful and where recipe books are available, they should be properly distributed to mothers. Nigerian Ministry of Health (1986) produced a booklet called "Nigerian Weaning Diets" that contains more than 40 recipes for weaning foods, while WHO/UNICEF (1988) produced similar booklets for health and community workers.

\section{CONCLUSION}

Traditionally produced complementary food have been in existence from time immemorial, however, results from literature have shown that it is grossly inadequate to meet daily nutrients, energy and micro-nutrients requirements of third world old infants and young children. The food is bulky and moisture dense than nutrients required by the old infants and young children, hence malnutrition is prevalent in these countries than developed countries. Previous results had shown that fortified cereal grains with legume increase its protein quality in term of lysine and tryptophan which is limiting factor in cereal grains, and enhance growth and development of old infants and young children. It's therefore, imperative for adequate processing methods, 
quality control, regulatory policy and implementation of complementary foods fortified with legume because of its antinutritional factors in order to safeguard the health of its consumers.

\section{REFERENCES}

Abbey, B. W. \& Nkanga, B. N. (1988). Production of high quality weaning products from maize, cowpea, crayfish mixture, Nutrition Reports International; 37(3), 951 - 957.

Adebowale, A. A., Sanni, L. O. \& Awonorin, S. O. (2005). Effect of texture modifier on the physicochemical and sensory properties of dried fufu. Food Science and Technology International; 11 (5), $373-382$.

Adeyemi, I. A. (1983). Dry-milling of sorghum for "ogi" manufacture. Journal of Cereal Science; 1, $221-227$.

Adeyeye, A. \& Ajewole, K. (1992). Chemical composition and fatty acid profiles of cereals in Nigeria. Food Chemistry; 44, 41 - 44.

Agu, V. C. (1976). Feeding and Weaning practices in Enugu, urban and rural. University of Nigeria, Nsukka, B. Sc. Thesis, (Unpublished).

Agyepong, E. \& Vallen, A. (1991). Improvement of weaning practices for the future. Bulletin of Noguchi Memorial Institute for Medical Research; 82 - 92.

Akingbala, J. O., Rooney, D. W. \& Faubon, J. M. (1981). Physical, Chemical and Sensory Ealuation of Ogi from sorhum of differing kernel characteristics. Journal of Food Science. 46, 1523 - 1526.

Akingbala, J. O. \& Rooney, D. W. (1990). Effect of flour particle texture and size on the consistency of sorghum 'tuwo'. Nigerian Food Journal; 8, $48-55$.

Akinrele, I. A. (1970). Fermentation studies on maize during the preparation of a traditional African starch-cake food. Journal of Science Food Agriculture; 21, 619 - 625

Akinrele, I. A. \& Edwards, C. C. A. (1971). An assessment of the nutritional value of maizesoy mixture "Soy-ogi" as a weaning food in Nigeria. British Journal of Nutrition; 26, 172 185.

Alector, V. A. \& Ojo, O. J. (1989). Changes in differently processed soybean (Glycine max) and lima bean (Phaseolus lunatus) with particular reference to their chemical composition and their mineral and some inherent antinutritional constituents. Die Nahrung; 33, $1009-1016$.

Amina, F. T. \& Agle, A. N. (2004). Infant and Child Survival in Nigeria. In proceeding of the $34^{\text {th }}$ Annual Conference and Scientific meeting of the Nutrition Society of Nigeria, Umudike, Abia State.

Aminu, R. F., Umeh, E. U. \& Singh, C. (2010). Enteric bacteria associated with 'balangwu' (readyto-eat meat product) sold in Anyigba, Kogi State. Nigerian Food Journal; 28(2), 171 176.

Ameny, M. A. \& Hegsted, M. (2006). Protein quality of weaning baby food from African white fleshed sweetpotato varieties and Apios Americana with pigeon peas added as a complementary protein. Journal of Food Science; 3(1), 126 134.

Anigo, K. M., Ameh, D. A., Ibrahim, S. \& Danbauchi, S. K. (2009). Nutrient composition of commonly used complementary foods in North Western Nigeria. African Journal of Biotechnology; 8(18), 4211 - 4216.

Anigo, K. M., Ameh, D. A., Ibrahim, S. \& Danbauchi, S. S. (2010). Nutrient composition of complementary food gruels formulated from malted cereals, soybean and groundnut for use in North-western Nigeria. African Journal of Food Science; 4(3), 65 - 72

Anju, S. S. (2002). Physicochemical properties and nutritional traits of millet-based weaning foods suitable for infants of the Kumaon hills. Northern India; 1440 - 1446.

Antai, S. P. \& Obong, U. S. (1992). The effect of fermentation on the nutrient status and some toxic components of Icacinia manni. Plant Foods for Human Nutrition; 42, 219 - 224.

Armar-Klemesu, M. A. \& Wheeler, E. F. (1987). Weaning practices and their outcome: A critical look with special reference to Ghana. Bulletin of Noguchi Memorial Institute for Medical Research; 23 - 24.

Babajide, J. M. (1998). Formulation and Biological Evaluation of Weaning foods from Cassava (Monihot esculenta) and Soybean (Glycine Max). University of Abeokuta, Nigeria, M. Sc Dissertation, (Unpublished).

Bajpai, S., Sharma, A. \& Gupta, M. N. (2005). Removal and recovery of antinutritional factors from soybean flour. Food Chemistry; 89, $497-501$.

Banigo, E. E. I., de-Man, J. M., \& Duitschaever, C. L. (1974). Utilization of high-lysine corn for the manufacture of ogi using a new, improved processing system. Cereal Chemistry; 51, $559-572$.

Bieri, D. M., Brosnan, J. T., Flatt, J. P., Hanson, R. W., Weird, W., Hellerstein, M. K., Jequier, E., Koletzko, B., Macdonald, I., Owen, O., \& Uany, R. (1999). Report of the IDECG Group on lower and upper limits of carbohydrate and fat intake. European Journal of Clinical Nutrition; 53, S177 - S199. 
Boralker, M. \& Reddy, S. (1985). Effects of roasting and germination on the digestibility of starch and protein present in soybean. Nutrition Reports International; 31, 833 - 839.

Bressani, R. \& Elias, L. G. (1983). Guideline for the development of processed and packaged weaning food. Food Nutrition Bulletin; 5(3), $57-64$.

Brown, K. H., Dewey, K. G. \& Allen, L. H. (1998). Complementary feeding of young children in developing countries: A review of current scientific knowledge. World Health Organization, Geneva. Available at: http://www.who.int/child-

adolescenthealth/Newpublicatons/NUTRITO N/WHO/NUT98.1.PDF.ACCESSED

September 10, 2002.

Cameron, N. \& Hofvander, J. (1983). Manual on Feeding Infants and Children. $3^{\text {rd }} \mathrm{Ed}$. London. Oxford Medical Publication.

Carcea, M. \& Acquistucci, R. (1997). Isolation physicochemical characterization of fonio (Digitaria exilisStapf) starch. Starch/Starke; 49(4), $131-135$.

Cherian, A. (1981). Attitudes and practices of infant feeding in Zaria. Ecological Food Nutrition; 11, $75-80$ (Access 2009).

Correia, I., Nunes, A., Duarte, I. F., Barros, A. \& Delgadillo, I. (2005). Sorghum followed by spectroscopic techniques. Food Chemistry; $90,853-859$.

Davidson, F. (2002). "Nutrition and Population" in Nutrition: A foundation for development, Geneva. ACC / SCN.

Desikachar, H. S. R. (1980). Development of weaning foods with high caloric density and low hotpaste viscosity using traditional technologies. Food Nutrition Bulletin; (4), 21 -23.

Dewey, K. G. (2001). Nutrition, growth and complementary feeding of the breastfed infant. Pediatric Clinilical Nutrition American; 48, $87-104$.

Dewey, K. G. \& Brown, K. H. (2002). Update on technical issues concerning complementary feeding of young children in developing countries and implications for intervention programs. Food Nutrition Bulletin; 24(1), 528.

Dewey, K. G. \& Brown, K. H. (2003). Update on technical issues concerning complementary feeding of young children in developing countries and implications for intervention programs. Food Nutrition Bulletin; 24(1), 5 28.

Dhingra, S. \& Jood, S. (2001). Organoleptic and nutritional evaluation of wheat breads supplemented with soybean and barley flour. Food Chemistry; 77, $479-488$.

Elegbede, J. A. (1998). Legumes. In: Nutritional quality of plant foods. Eds. Osagie, A. U. and
Eka, O. U. Benin City. Ambik Press. 53 83pp.

Ene-Obong, H. N. (1993). Nutritional evaluation, consumption pattern and processing of the African yam beans (Sphenostylis stenocarpa). University of Nigeria, Nsukka, Ph.D. Thesis, Unpublished.

Ezeocha, V. C. \& Onwuka, G. I. (2010). Effect of processing methods on the physic-chemical and nutritional quality of maize and soybean based complementary blends. Nigerian Food Journal; 28(2), 210 - 216.

FAO/WHO/UNU. (1985). Energy and Protein Requirements. FAO/WHO Nutrition Meetings, Report Series 724. Food and Agriculture Organization / World Health Organization, Geneva.

FAO/WHO. (1991). Expert Consultation: Protein quality evaluation, $\mathrm{FAO}$ WHO Nutrition Meetings, Report series 51, Food and Agricultural Organization / World Health Organization, Rome.

FAO/WHO. (2002). Human vitamins and mineral requirements. Report of a joint FAO/WHO expert consultation on zinc. FAO Food and Nutrition paper 56, FAO/WHO, Rome, Italy.

Fannon, J. E., Hauber, R. J. \& BeMiller, J. N. (1992). Surfaces pores of starch granules Cereal Chemistry; 69, $284-288$.

Fashakin, J. B., Awayefa, M. B., \& Furst, P. (1986). The application of protein concentrates from locally available legumes in development of weaning foods. Journal of Nutrition Science Ernahrungswisse; 25, 220 - 227.

Fernandez, D. E., Vanderjagt, D. J., Williams, M., Huag, Y. S., Chuang, L., Millson, M., Andrew, R., Pastuszyn, A. \& Glew, R. H. (2002). Fatty acids, amino acids, and trace mineral analyses of five weaning foods from Jos, Nigeria. Plant Foods for Human Nutriton; $52,257-274$.

Figueroa, R. \& Rodriguez-Garcia, R. (2002). 'Nutrition and population' in Nutrition: A foundation for Development, Geneva.

Gibson, R. S. (2000). The Adequacy of Micronutrients in Complementary Foods. Pediatrics; 106(5), $1298-1299$.

Grifflin, I. J. \& Abrams, S. A. (2001). Iron and Breastfeeding. Pediatrics Clinical Nutrition American; 48, 401 - 414.

Hoppe, C., Molgaard., Juul, A., Schack-Nielsen. L., Barkholt, V. \& Michaelsen, K. F. (2003). Animal protein intake, s-IFG-1 and growth in healthy $2 \frac{1}{2}$ year old children. FASEB Journal; 17(4), A729.

Huffman, S. L., Oniong'o, R. \& Quinn, V. (2000). Improving young child feeding with processed complementary cereals and behavior change in Kenya. Food and Nutrition Bulletin; (In press). 
Idowu, M. A., Adeyemi, I. A., \& David, M. (1993). Sensory evaluation and nutrient composition of weaning food from pre-gelatinized maizepotato mixture. Plant Foods for Human Nutrition; 44, 149 - 155.

Igah, S. A. (2008). Target food sources for formulating complementary foods for weaning purposes-A review. Bayero Journal of Pure and Applied Sciences; 1(1), $20-27$.

Igyor, M. A., Yusufu, P. A. \& Sengev, I. A. (2010). Evaluation of physicochemical, functional and sensory properties of fermented fura powder supplemented with soy. Nigerian Food Journal; 28(2), $454-462$.

Ihekoronye, A. I. \& Ngoddy, P. O. (1985). Integrated Food Science and Technology for the tropics. London. Macmillan Press Ltd.

Ikegwu, O. J. 2010). Effect of processing on the physicochemical and pasting properties of Brachystegia eurycoma flour. Nigerian Food Journal; 28 (2), 193 - 202.

Ikujendola, V. A. \& Fashakin, J. B. (2005). The physicochemical properties of a complementary diet prepared from vegetable proteins. Journal of Food Agriculture. Environment; 3 (3 and 4), $23-26$.

Jideani, A. I. \& Akingbala, J.O. (1993). Some physicochemical properties of acha (D. exilis Stapf) and iburu (D. iburua Stapf) grains. Journal of Science of Food and Agriculture; 63, $369-374$.

Jonsyn, F. E. (1985). Fungi associated with selected fermented food-stuffs in Seirra Leone. In: Prage L, (ed.) Development of indigenous fermented food and food technology in Africa. Proceedings of the IFS/UNU Workshop held in Duala, Cameroon, October 1985. Provisional Report No. 20. Stockholm: International Foundation for Science: 169 181.

Juke, M., Mcguire, J., Method, F., \& Sternberg, R. (2002). Nutrition Education in Nutrition: A Foundation for Development. Geneva.

June, E. R., Masako, A. \& Blanshara, J. M. V. (1991). The physicochemical properties of cassava starch. Tropical Science; 31, $189-207$.

Keku, K.O. (2006). Production, Chemical Composition and Storage Stability of "Ampla". A Breakfast Meal Form Mixture of Roasted Maize and Soybean. University of Abeokuta, Nigeira, M.Sc. Dissertation, Unpublished.

Ketiku, A. \& Ayoku, S. (1984). Nutritional studies of a Nigerian multi-mix weaning food - Apapa multi-mix. Nigerian Journal of Nutrition Science; $5,39-45$.

Kordylas, J. M. (1990). Processing and Preservation of Tropical and Sub-Tropical Foods. London and Bsingstoke. Macmillan Publisher Ltd. $350-374 p p$.
Lasekan, O. O. (1996). Effects of Germination of Alpha amylase activities and rheological properties of sorghum (Sorghum bicolor) and acha (Digitaria exillis) grains. Journal of Food Science and Technology; 33(4), 329 331.

Layman, D. K. (2003). The role of leucine in weight loss diets and glucose homeostasis. Journal of Nutrition; 13, 261S - 267S.

Lutter, C. K. \& Rivera, J. (2003). Nutritional status of infants and young children and characteristics of their diets. Journal of Nutrition; 133, 2941S - 2949S.

Lutter, C. K. \& Dewey, K. G. (2007). Proposed nutrient composition for fortified complementary foods. American Journal of Clinical Nutrition; 86(2), $412-420$.

Makinde, M. A. \& Lachance, P. A. (1976). Tryptophan, the first limiting amino acid in "ogi". Nutrition Reports International; 14, 671 $-679$.

Martin, H., Laswai, H. \& Kulwa, K. (2010). Nutrient content and acceptability of soybean based complementary food. African Journal of Food, Agriculture, Nutrition and Development; 10(1), $1684-5358$.

Matilda, A., Nilsen, R., Lie, O. \& Lied, E. (1993). Effect of processing (Sprouting and/or fermentation) on sorghum and maize. In: Proximate composition, minerals and fatty acids. Food Chemistry; 46, $351-353$.

Matz, S.A. (1984). Puffed Snacks: In snack food technology. $2^{\text {nd }}$ edition. Avi, West Port CT 150. $165 \mathrm{pp}$.

Mestres, C., Matencio, F. \& Louis-Alexandre, A. (1995). A mechanical of corn kernels development of a laboratory friability test that can predict milling behaviour. Cereal Chemistry; 72, $652-657$.

Mora-Escobedo, R., Paredes-Lopez, O. \& QutienezLopez, G. F. (1991). Effect of germination on the rheological and functional properties of amaranth seeds. Lebensmittel-Wissenschaft und Technologie; 24, $241-244$.

Muhimbula, H. S., Issa-Zcharia, A., \& Kinabo, J. (2011). Formulation and sensory evaluation of complementary foods from local, cheap and readily available cereals and legumes in Iringa, Tanzania. African Journal of Food Science; 5(1), $26-31$.

Ngwu, E.K. (2005). Innovative Infant Feeding Practices and Nutrition. Journal of Home Economics Research; 6(2), 25-32.

Nnanyelugo, D. O. (1985). Nutritional status of children in Anambra State: A comprehensive treatise. Nsukka. University of Nigeria Press.

Nnanyelugo, D. O., Ngoddy, P.O., Uwaegbute, A. C., Okeke, E. C., Ene-Obong, H. N., Ngwu, E. K., McWalters, K., \& Phillips, D. (1990). 
Impact of village mill technology in Nigeria. In: Barnes-McConnell P. ed. Ten years of collaborative research on beans and cowpeas. Proceedings of the International Seminar on Beans/Cowpea CRSP held in East Lansing, Michigan, April $30-3^{\text {rd }}$ May, USA: Michigan State University, $46-49$.

Nout, M. J. R. (1995). Weaning Foods for Tropical Climates. Traditional African Foods Quality and Nutrition; $23-31$.

Nout, M. J. R. \& Ngoddy, P. O. (1995). Technology Aspects of Preparing Affordable Fermented Weaning Foods. Paper Prepared for Presentation at joint FAO/WHO Workshops on Assessment of Fermentation as a Household Technology for Improving Food Safety. Pretoria, South Africa. 1-15.

Nwasike, C. C., Okoh, P. N., Aduku, A. O. \& Njoku, P. C. (1987). Proximate, mineral and amino acid composition of early and late season millets. Der trppenlandwirt Zeitschrift Fur Die landwirtschaft in den Trpen and Subtropen; $88,67-73$.

Obatolu, V. A., Cole, A. H. \& Maziya-Dixon B. B. (2000). Nutritional quality of complementary food prepared from unmalted and malted maize fortified with cowpea using extrusion. Journal of Science, Food and Agriculture; 80(6), $646-650$.

Obizoba, I. C. \& Atti, J. V. (1991). Effect of soaking, sprouting, fermentation and cooking on the nutrition composition and some antinutritional factors of sorghum (Guinesia) seeds. Plant Foods for Human Nutrition; 41, 203.

Obizoba, I. C. \& Egbuna, H. I. (1992). Effect of germination and fermentation on the nutritional quality of bambara nut (Voandzeia subterranean. Thauars) and its product (Milk). Plant Foods for Human Nutrition; 42, $13-23$.

Obizoba, I. C. (1998). Fermented Foods. In: Nutritional quality of plant foods. Eds. Osagie, A. U. and Eka, O. U. Benin City. Ambik press. $160-198 p p$.

Oganah, B. C. (2005). Nutrition and Child Survival: The fate of the Nigerian Child. Journal of Home Economics Research; 6(1), 23 - 27.

Olguin, M. C., Hisano, N., D'Ottavio, A. E., Zingale, M. I., Revelant, G. C. \& Calderari, S. A. (2003). Nutritional and antinutritional aspects of Argentina soy flour assessed on weaning rats. Journal of Food Composition and Analysis; 16, 441 - 449.

Ologhobo, A. D., Fetuga, B. L. \& Tewe, O. O. (1984). The cyanogenic glycoside contents of raw and processed lima bean varieties. Food Chemistry; 13, $117-128$.

Olusanya, J. O. (1998). Nutrient evaluation of some home prepared multimixes for use as weaning food in Nigeria. University of
Ibadan, Ibadan, Nigeria, Ph.D Thesis. Unpublished.

Okoh, P. N., Nwasike, C. C. \& Ikediobi, C. D. (1985). Studies on seed proteins of millet. In: Amino acid composition of protein fractions of early and late maturing varieties. Journal of Agriculture Food Chemistry; 33, $55-57$.

Okoh, P. N. (1998). Cereal grains: Nutritional quality of plant foods. In: Anthony, U. Osagie and Offiong, U. Eka, Eds. Post Harvest Research Unit, Department of Biochemistry, University of Benin, Nigeria.

Omueti, O., Oguntona, E. B., Jaiyeola, O. \& Ashaye, O. A. (2000). Nutritional evaluation of homeprepared soy-corn milk - A Protein Beverage. Nutrition and Food Science; 30(3), 128 - 132.

Onabanjo, O. O. (2007). Formulation and Biological Evaluation of Weaning Foods from Cassava (Manihot esculenta), soybean (Glycine max), groundnut (Arachis hypogaea), Cassava leaves, and Carot (Daucus carota). University of Abeokuta, Nigeria, Ph.D Dissertation, Unpublished.

Onabanjo, O. O., Oguntona, C. R. B., Maziya-Dixon, B., Olayiwola, I. O., Oguntona, E. B. \& Dixon, A. G. O. (2008). Nutritional Evaluation of four Optimized Cassava-Based Complementary Foods. Africa Journal of Food Science; 2, $136-142$.

Onofiok, N. \& Nnanyelugo, D. O. (1992). Nutrient intake of infants of high and low socioeconomic groups in Nsukka, Nigeria. Occasional Paper. Nsukka: Department of Home Science and Nutrition, University of Nigeria.

Onofiok, N. O. \& Nnanyelugo, D. K. (2007). Weaning Foods in West Africa: Nutritonal Problems and Possible Solutions. www.unu.edu/unupress/food/v191e/begin.ht m. Accessed end June 2009.

Onuorah, C. E. \& Akinjide, F. A. (2004). Comparative evaluation of four formulated weaning foods and a commercial product. Nigerian Food Journal; 22, 48 - 53.

Osagie, A. U. (1998). Antinutritional factors. In: Nutritional quality of plant foods. Eds. Osagie, A. U. and Eka, O. U. Benin City. Ambik press. Pp: 221- 244.

Oshaug, A. \& Haddad, L. (2002). 'Nutrition and Agriculture' in Nutrition: A foundation for development, Geneva.

Oyewole, O. B. \& Akingbala, J. O. (1993). Acha (Digitaria exilis): A little known cereal with high potential. UNAAB Series, No. 3.

Phillips, R. D. \& McWatters, K. H. (1991). Contribution of cowpeas to Nutrition and health. Food Technology; 45, $127-130$.

Rapley, G. (2006). Baby-Led Weaning. A developmental approach to the introduction of complementary foods. In Hall Moran, V 
and Dykes, F. Eds. Maternal and Infant Nutrition and Nurture: Controversies and Challenges, London. QUAY Books, 275 298pp.

Reeds, P. J. \& Garlick, P. J. (2003). Protein and amino acid requirements and the composition of complementary foods. Journal of Nutrition; 133, 2953S - 2961S.

Riet, W. B., Van der Weight, A. W., Cilliers, J. J. L. \& Datel, J. M. (1987). Food chemical analysis of tempeh prepared from South Africangrown soybeans. Food Chemistry. 25, 197 206.

Ruel, M. T. (2003). Milk intake is associated with better growth in Latin America: evidence from the Demographic and Health Surveys. FASEB Journal; 17(4), A1199 (abs).

Salami, I. I. \& Ojo, A. K. (2004). Dietary pattern and nutritional status of children in Ekiadolor: A rural setting in Edo State. Journal of Home Economics Research; 5(3), $72-76$.

Sanni, A. I., Onilude, A. A. \& Ibidapo, O. T. (1999). Biochemical composition of infant weaning food fabricated from blends cereals and soybean. Food Chemistry; 65, 35- 39.

Sanni, L. O., Ikuomola, D. P. \& Sanni, S. A. (2001). Effect of length of fermentation and varieties on the qualities sweet potato gari. Proceeding $8^{\text {th }}$ triennial symposium of the international Society for tropical root Crops Africa Branch (ISTRC-AB). Ed M. O. Akoroda, IITA, Ibadan, Nigeria, November 12 - 16. 208 -211pp

Sanni, L. O., Kosoko, S. B., Adebowale, A. A. \& Adeoye, R. J. (2004. The influence of palm oil and chemical modification on the pasting and sensory properties of fufu flour. International Journal of Food Properties; 7(2), $229-237$.

Simango, C. (1997). Potential use of traditional fermented foods for weaning in Zimbabwe. Journal of Social Science and Medicine; 44(7), $1065-1086$.

Sizer, F. \& Whitney, E. (2002). Nutrition. Concepts and Controversies. $8^{\text {th }} \mathrm{Ed}$. Belmont, USA. Wadworth Thomson Learning.

Solomon, M. (2005). Nutritive value of three potential complementary foods based on cereals and legumes. African Journal of Food and Nutritional Science; 5, 2: $1-14$.

Srinivas, I., Bhashyam, M. K., Manjunath, N. \& Gowda, K. T. P. (1991). Influence of cob and grain characteristics on the processing properties of maize. Tropical Science; 31, $305-316$.

Storebakken, T., Refstie, S., \& Ruyter, B. (2000). Soy products as fat and protein sources in fish feed for intensive aquaculture. In J. K. Drackley (eds.) Soy in Animal Nutrition.
Savoy, I. L. Federation of Animal Science Society, 127 - 170pp.

Svanberg, U. (1987). Dietary Bulk in Weaning Foods and Its Effect on Food and Energy Intake. In: Alnwick, D. Moses, S. Schmidt OG, Eds. Improving Young Child Feeding in Eastern and Southern Africa. Nairobi, New York, Stockholm: IDRC, UNICEF, SIDA, 272 - 287.

Swinkles, J. J. M. (1985). Composition and properties of commercial native starches. Starch/Starke; 37(1), 1 - 5.

Takeda, Y., Huzukuri, S., Takede, C. \& Sukuki, A. (1987). Structure of branched molecules of amylase of various origins and molar fractions of branched and un-branched molecules. Carbohydrate Research; 165, $139-145$.

Tester, R. T. \& Morrison, W. R. (1990). Swelling and gelatinization of cereal starch. In: Effects of amylopectin, amylase and lipids. Cereal Chemistry; 67, $551-557$.

Uauy, R. \& Castillo, C. (2003). Lipid requirements of infants: implications for nutrient composition of fortified complementary foods. Journal of Nutrition; 133, 2962S - 2972S.

UNICEF (2009). Tracking progress on child and maternal nutrition. A survival and development priority. New York, NY 10017, USA.

Uwaegbute, A. C. \& Nnanyelugo, D. O. (1987). Usage patterns of cow-peas (Vigna unguiculata) for infant feeding in Nigeria. in: Kwik Whei L, Kiang Ai K, eds. Trends in nutrition and food policy. In proceedings of the $7^{\text {th }}$ World Congress of Food Science and Technology. Singapore: Institute of Food Science and Technology; $201-205$.

Walker, S. D., Gavin, K. A., Ashworth, A. \& Gardner, J. N. (2002). Complementary foods in Jamaica. Viscosity energy density and feeding practices. Public Health Nutrition; 5(2), $295-302$.

Wankhede, D. B., Deshpande, h. W., Gunjal, B. B. Bhosale, M. B., Patil, H. B., Gahilod, A. T. Sawate, A. R. \& Walde, S. G. (1989). Studies on physicochemical pasting characteristics and amylolytic susceptibility of starch from sorghum (Sorghum bicolor) grains. Starch/Starke; 41, $123-127$.

Weingartner, K. E., Dashield, K. E. \& Nelson, A. (1987). Soybean utilization in Africa: making a place for a new food. Food Nutrition; 13, No. 2. FAO/UN, Rome.

Whitney, E. N., Caaldo, C. B., \& Rolfes, S. R. (2002). Understanding normal and clinical nutrition. $6^{\text {th }}$ Ed. Belmont, USA. Wadworth / Thomson Learning.

WHO (1998). Complementary Feeding of young children in Developing Countries: A review of 
current scientific knowledge. World Health Organization, Geneva, Switzerland.

WHO (2000). Complementary feeding - family foods for breastfed children. WHO. Geneva Available at:http//www/who.int/child adolescenthealth/NewPiblications/ Nutrition/ complefeed.pdf. (Accessed September 10, 2010).

WHO (2002). Turning the Tide of malnutrition. Responding to the challenge of the $21^{\text {st }}$ Century. www.who.int/nut/documents/nhdbrochure.pdf; Accessed end May, 2010.
WHO (2003). Guiding principles for complementary feeding of the breastfed child. (WH/A56/INFO.DOC.) Geneva, Switzerland.

WHO (2005). Guiding principles for complementary feeding of the non-breastfed child Geneva, Switzerland.

WHO/UNICEF (1988). Weaning from breast milk to family food. A guide for health and community workers. Geneva. World Health Organization.

Cite this Article: Akinsola AO, Onabanjo OO, Idowu MA, and Ade-Omowaye BIO (2017). Traditional Complementary Foods: A Critical Review. Greener Journal of Agricultural Sciences, 7(8): 226-242, http://doi.org/10.15580/GJAS.2017.9.092217137. 